Ocean Sci. Discuss., 4, 897-931, 2007

www.ocean-sci-discuss.net/4/897/2007/

(C) Author(s) 2007. This work is licensed

under a Creative Commons License.
OSD

4, 897-931, 2007

Available energy in the Barents Sea

R. C. Levine and

D. J. Webb

\section{On available energy in the ocean and its application to the Barents Sea}

R. C. Levine ${ }^{1}$ and D. J. Webb ${ }^{2}$

${ }^{1}$ Department of Geography, University of Sheffield, UK

${ }^{2}$ National Oceanography Centre, Southampton, UK

Received: 12 November 2007 - Accepted: 12 November 2007 - Published: 27 November 2007

Correspondence to: D. J. Webb (david.webb@noc.soton.ac.uk)
Title Page

Abstract

Introduction

Conclusions

References

Tables

Figures

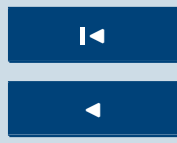

Back

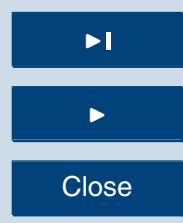

Full Screen / Esc

Printer-friendly Version

Interactive Discussion 


\section{Abstract}

Following meteorological practice the definition of available potential energy in the ocean is conventionally defined in terms of the properties of the global ocean. However there is also a requirement for a localised definition, for example the energy released

5 when shelf water cascades down a continental shelf in the Arctic and enters a boundary current.

In this note we start from first principals to obtain an exact expression for the available energy $(A E)$ in such a situation. We show that the available energy depends on enstrophy and gravity. We also show that it is exactly equal to the work done by the pressure gradient and by buoyancy.

The results are used to investigate the distribution of $A E$ in the Barents Sea and surrounding regions relative to the interior of the Arctic Ocean. We find that water entering the Barents Sea from the Atlantic already has a high $A E$, that it is increased by cooling but that much of the increase is lost overcoming turbulence during the passage 15 through the region to the Arctic Ocean. However on entering the Arctic enough available energy remains to drive a significant current around the margin of the ocean. The core of raised available energy also acts as a tracer which can be followed along the continental slope beyond the dateline.

\section{Introduction}

20 Recently Levine (2005) investigated the dynamic height or pressure field of the Arctic Ocean making use of results from the OCCAM global ocean model (Webb et al., 1998). He found that along the boundary of the Arctic, at depths of a few hundred metres, the largest dynamic heights occur where dense Barents Sea shelf water cascades down the continental slope in the St Anna Trough. This water becomes part of a boundary current whose waters can be followed eastwards around the Arctic and out in the Atlantic as far as Cape Hatteras.
OSD

4, 897-931, 2007

Available energy in the Barents Sea

R. C. Levine and

D. J. Webb

\section{Title Page}

Abstract

\section{Full Screen / Esc}

Printer-friendly Version

Interactive Discussion 
This result raises a number of questions concerning the energetics of the flow. Boundary currents need energy to start the current and to overcome boundary turbulence. So how much of the energy available to the current comes from the release of potential energy as the water descends the St Anna Trough? What effects do the 5 density changes due to cooling and ice formation in the Barents Sea have on the process? How much of the energy is implicit in the water flowing into the Barents Sea from the Atlantic? We also need to know how changes in internal energy and, in analogy to Bernouilli's equation, the large scale oceanic pressure field may also be involved.

If we concentrate first on gravitational potential energy, previous studies of the ocean 10 have been based on the atmospheric definition of Available Potential Energy ( $A P E)$. Lorenz (1955) defined this to be the difference between the Potential Energy $(P E)$ of the atmosphere under study and the $P E$ of a reference atmosphere produced by moving the air parcels adiabatically (i.e. reversibly) so that the atmosphere reaches its minimum $P E$ state. Thus,

$15 \quad A P E=\int_{V_{1}} g \rho z d V-\int_{V_{2}} g \rho_{r} z d V$,

where $\rho$ is the density, $\rho_{r}$ the density of the reference system, $z$ is height, and the integrals are over the volume of the original system $V_{1}$, and the reference system $V_{2}$.

However for our study we are more interested in the energy available to the current while it is in the Arctic. Thus we need the potential energy relative to the offshore 20 Arctic Ocean. We also should include changes in internal energy. For a perfect gas, the global change of internal energy is proportional to the APE (Wells, 1997), a result which is often sufficient for atmospheric studies. For the ocean, with its more complex equation of state, we need to be more specific.

Finally we need to include the effects of pressure. A boundary current is usually 25 driven by pressure differences along the current, the energy for the process ultimately coming from changes in potential or internal energy elsewhere in the system. If the energy for the Arctic boundary current comes ultimately from outside the region then the large scale pressure field should contain this information.
OSD

4, 897-931, 2007

Available energy in the Barents Sea

R. C. Levine and

D. J. Webb

Title Page

Abstract

Introduction

Conclusions

Tables

References

Figures

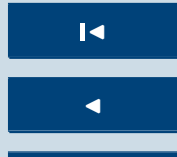

$\Delta$

Back

Close

Full Screen / Esc

Printer-friendly Version

Interactive Discussion

EGU 
To make some sense of this we start from some fairly basic thermodynamics and investigate the energy released when a parcel of water is transferred from one region of ocean, at a depth $z_{1}$ and pressure $P_{1}$, to a second region of ocean, at depth $z_{2}$ and pressure $P_{2}$. As energy is a conserved quantity, this equals the total energy released 5 when the parcel is extracted for the ocean at pressure $P_{1}$, moved vertically from $z_{1}$ to $z_{2}$ and injected back into the ocean at pressure $P_{2}$.

We show that if the parcel of water stays within the ocean, then this equals the energy change due to the horizontal pressure gradient and vertical buoyancy forces, the total being independent of the path chosen. The result thus includes the contribution of 10 gravity and pressure but we show that it also includes the contribution of any change in internal energy. The form of the equation also allows us to split the total energy available, at each point in the fluid, into its gravitational and pressure components.

In writing this paper we have had a problem in the correct description of the energy available to drive a current. The terms potential energy or relative potential energy 15 are are obviously wrong because they leave out the contribution of pressure and internal energy. Relative enthalpy has a similar problem. It includes the internal energy and pressure components but leaves out gravity. We therefor use the term available energy $(A E)$ with the understanding that a more apt description is always welcome (see Appendix 2).

20 As an example of how the concept may be used, we investigate the distribution of $A E$ in the water masses passing through the Barents Sea into the Arctic Ocean. We find that the inflowing Atlantic water has a large $A E$ compared to the central Arctic, that the $A E$ increases as the water flows through the Barents Sea, but that much of the increase is later lost overcoming turbulence. However on entering the Arctic Ocean enough $A E$ remains to drive a significant current around the margin of the ocean. The core of raised available energy also acts as a tracer which can be followed far along the continental slope.
OSD

4, 897-931, 2007

Available energy in the Barents Sea

R. C. Levine and

D. J. Webb

\section{Title Page}

\section{Full Screen / Esc}

Printer-friendly Version

Interactive Discussion 


\section{Internal energy and enthalpy}

As shown in many textbooks (Pippard, 1961), the internal energy $\Delta U$ of a mass of fluid may be changed by the addition or removal of heat $Q$ or mechanical energy $W$,

$\Delta U=Q+W$

5 By convention such quantities are defined per unit mass of fluid. If a change is carried out adiabatically, then there is no heating or cooling and $Q$ is zero. If in addition the only mechanical energy change is due to compression then $W$ is equal to $-P d V$, where $P$ is the pressure and $d V$ is the change in volume. Thus for adiabatic changes in the ocean,

$d U=-P d V$

To calculate the available energy of a small parcel of water, we first consider how much energy is required to move it into position from a reservoir at the same depth using a piston. If the fluid in a reservoir is at pressure $P_{r}$ and the ocean at pressure $P_{1}$ then the work required to do this $W_{1}$ is given by,

${ }_{15} \quad W_{1}=-\int_{V_{r}}^{V_{1}} P d V+P_{1} V_{1}-P_{r} V_{r}$

where $V_{r}$ and $V_{1}$ are the volume per unit mass before and after injection. Physically, the first term on the r.h.s is the change in internal energy, the work expended by the piston during the initial compression phase when the pressure increases from $P_{r}$ to $P_{1}$ and the volume decreases from $V_{r}$ to $V_{1}$. The term $P_{1} V_{1}$ is the work expended by the piston pushing fluid into the ocean at pressure $P_{1}$ and the last term is the help given to the piston by the pressure from the reservoir as the fluid is injected ${ }^{1}$.

\footnotetext{
${ }^{1}$ Pumping up a bicycle tyre is similar with an initial compression stage followed by an (approximately) constant pressure injection stage.
}

Available energy in the Barents Sea

R. C. Levine and D. J. Webb

\section{Title Page}

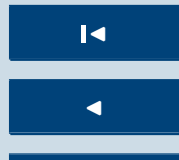

\section{Full Screen / Esc}

Printer-friendly Version

Interactive Discussion

EGU 
If the injection occurs at the bottom of the ocean, then the term $P_{1} V_{1}$ is also the energy required to raise the column of water above the point of injection to make way for the injected water. This is because the pressure equals the weight of the column of water,

${ }_{5} \quad P_{1}=g \int_{z_{1}}^{z_{0}} \rho(z) d z$

where $z_{0}$ is the ocean surface. So, if the column has unit area, it is raised by a distance $V_{1}$. Thus,

$P_{1} V_{1}=\int_{z_{0}}^{z_{1}}\left(g \rho(z) V_{1}\right) d z$

is the total change in potential energy of the column. If the injection is above the ocean 10 bed, the injected water compresses the deeper water slightly, so some of the energy goes into extra internal energy of the deeper water.

A more compact form of the energy involved can be obtained in terms of the thermodynamic quantity enthalpy $H$. This is defined as,

$H=U+P V$.

15 Using this, Eq. (4) simplifies to become,

$W_{1}=H_{1}-H_{r}$,

where $H_{r}$ and $H_{1}$ are the enthalpies of the fluid before and after injection.

If the reservoir and injection points are at different depths, then there is also a change in gravitational potential energy. The total energy change, the available energy, is thus,

$20 \quad A E=\left(H_{1}+g z_{1}\right)-\left(H_{r}+g z_{r}\right)$.

where $z_{1}$ and $z_{r}$ are the heights of the injection point and the reservoir respectively.
OSD

4, 897-931, 2007

Available energy in the Barents Sea

R. C. Levine and

D. J. Webb

Title Page

Abstract

Introduction

Conclusions

Tables

References

Figures

14

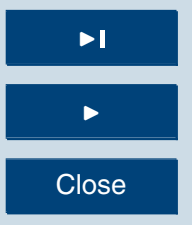

Back

Close

Full Screen / Esc

Printer-friendly Version

Interactive Discussion 
The result is related to Bernoulli's equation for a fluid in a gravitational field. If the two points are joined by a streamline and if the flow is both inviscid and adiabatic, then the available energy equals the change in kinetic energy per unit mass (Landau and Lifshitz, 1959) along the streamline. If the fluid is also incompressible, $V$ is a constant, 5 so $H$ equals $P / \rho$ and $A E$ equals the change of $(P / \rho+g z)$. The latter is often called the Montgomery potential.

For the problem considered later in this paper, the points may not be linked by steamlines, the flow may not be adiabatic and much of the energy may be lost in turbulence. However the concept of available energy is still useful because of the insight it provides 10 into the energy potentially available at each point in the flow.

\section{Available energy as a path integral}

The expression for $A E$ (Eq. 9) depends on scalar quantities $H$ and $z$, both of which are continuous throughout the ocean. As a result the equation can be rewritten as a path integral between the initial and final points $S_{1}$ and $S_{2}$. Thus,

${ }_{15} A E=\int_{S_{1}}^{S_{2}} d \mathbf{s} \cdot(\nabla H+g \hat{\mathbf{z}})$.

From Eq. (7),

$\nabla H=\nabla U+\nabla(P V)=-P \nabla V+\nabla(P V)=V \nabla P$

The volume per unit mass $(V)$ is the inverse of the density $\rho$, so,

$A E=\int_{S_{1}}^{S_{2}} d \mathbf{s} \cdot V(\nabla P+g \rho \hat{\mathbf{z}})$,
OSD

4, 897-931, 2007

Available energy in the Barents Sea

R. C. Levine and

D. J. Webb

Title Page

Abstract

Introduction

Conclusions

References

Tables

Figures

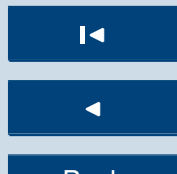

$\Delta$

Back

Close

Full Screen / Esc

Printer-friendly Version

Interactive Discussion 
the first term on the r.h.s including both the effects of the pressure gradient and any change in internal energy. If the ocean is in hydrostatic balance,

OSD

$A E=\int_{S_{1}}^{S_{2}} d \mathbf{s} \cdot V\left(\nabla_{h} P+g\left(\rho-\rho_{O}\right) \hat{\mathbf{z}}\right)$,

where $\nabla_{h}$ denotes the horizontal version of the gradient operator and $\rho_{0}$ is the ambient 5 density field. At each point along the path, the force per unit volume acting on the parcel of water is,

$F=\nabla_{h} P+g\left(\rho-\rho_{0}\right) \hat{\mathbf{z}}$

the second term corresponding to Archimedes' Principle.

For analysing the available energy of shelf waters relative to the neighbouring ocean 10 it is convenient to split the path integral of Eq. (13) into a horizontal section, in which the water is first moved horizontally without change in depth, and a vertical section, in which energy is released as the partical moves vertically, within a reference water column, to a final depth where it has the same density as the surrounding water mass. Thus,

$15 A E=A E_{p}+A E_{g}$,

$$
\begin{aligned}
A E_{p} & =\int_{S_{1}}^{S_{2}^{\prime}} d \mathbf{s} \cdot \mathbf{V} \nabla_{\mathbf{h}} \mathbf{P}, \\
& =\int_{P_{1}}^{P_{2}} d P V
\end{aligned}
$$

is the contribution from the constant depth section and

$20 \quad A E_{g}=\int_{z_{1}}^{z_{2}} d z V g\left(\rho-\rho_{0}\right)$

4, 897-931, 2007

Available energy in the Barents Sea

R. C. Levine and

D. J. Webb

Title Page

Abstract

Introduction

Conclusions

References

Tables

Figures

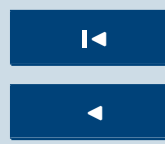

Back

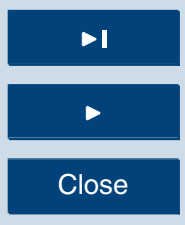

Full Screen / Esc

Printer-friendly Version

Interactive Discussion 
is the contribution from the final vertical section. Here $z_{1}$ and $z_{2}$ are the initial and final depths and $P_{1}$ and $P_{2}$ are the pressures at points $S_{1}$ and $S_{2}^{\prime}$, the latter being at the final geographical position but at the initial depth. In the rest of this paper we refer to $A E_{p}$ and $A E_{g}$ as the pressure and gravitational contributions to the Available Energy.

OSD

4, 897-931, 2007

As $V$ equals $1 / \rho$, and $\rho$ is almost constant within the ocean,

$A E_{p} \approx\left(P_{1}-P_{2}\right) / \rho^{\prime}$

$A E_{g} \approx\left(1 / \rho^{\prime}\right) \int_{z_{1}}^{z_{2}} d z g\left(\rho-\rho_{0}\right)$

where $\rho^{\prime}$ is a typical density in the region. The approximation is similar to that used in 10 Eq. (1), in that it ignores the changing internal energy due to changes in pressure. The size of the error introduced depends on the range of densities involved but will usually be of order $1 \%$ of the total or less.

If $A E_{p}^{\prime}$ and $A E_{g}^{\prime}$ represent the corresponding values per unit volume, then to the same approximation,

$15 A E_{p}^{\prime} \approx\left(P_{1}-P_{2}\right)$,

$A E_{g}^{\prime} \approx \int_{z_{1}}^{z_{2}} d z g\left(\rho-\rho_{0}\right)$

\section{Available energy in the Barents Sea}

As an example of how these concepts may be used, we consider the results from a

model study of the flow through the Barents Sea towards the St. Anna Trough. The data that we use comes from a run of the $1 / 12^{\circ}$ version of the OCCAM global ocean model (Webb et al., 1998; Coward and de Cuevas, 2005).

Title Page

Abstract

Introduction

Conclusions

Tables

References

Figures

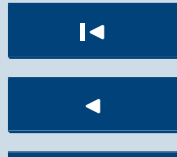

Back

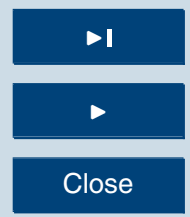

Full Screen / Esc

Printer-friendly Version

Interactive Discussion 
The model is forced by NCAR surface fluxes and the run presently covers the period 1985 to 2004. Time series from the Barents Sea region of the model show year to year variability but no long term drift. The model Barents Sea is well mixed in the vertical at the end of winter and becomes stratified during the summer months with a warmer and 5 fresher surface layer. For the results presented here we used the monthly averaged model data from February 1998.

\subsection{The Barents Sea water masses}

The Barents Sea (Fig. 1) is a relatively deep region of continental shelf, with large areas below $200 \mathrm{~m}$. The main central region is connected to the Norwegian Sea in the 10 west via a deep trough, the Bear Island Trough, with depths below $400 \mathrm{~m}$. In the northeast there is an even deeper trough, the St Anna Trough, with depths below $500 \mathrm{~m}$ connecting the region to the Arctic Ocean. The velocity field from the model shows a significant flow between the two troughs, the main restriction to the flow appearing to be a narrow sill near $57.5^{\circ} \mathrm{E} 78^{\circ} \mathrm{N}$, with a depth of approximately $200 \mathrm{~m}$.

15 Figures 2 and 3 show the mean temperature and salinity on model level 21 in February 1998. This model level has a central depth of $205 \mathrm{~m}$ and a thickness of $20 \mathrm{~m}$ and so includes the lowest water mass passing through the sill. In the south-west, warm $\left(>5^{\circ} \mathrm{C}\right)$ water enters the Barents Sea along the southern edge of the trough. Offshore this is saline (>34.9) Atlantic Water but there is also a fresher coastal current with 20 salinities below 34.5. This water is cooled and freshened in the Barents Sea, part then returns west to join the West Spitzbergen Current and part flows northwards, eventually entering the Arctic near $45^{\circ} \mathrm{E}$.

The remainder continues east, where at the end of winter it forms a large water mass in the Central Basin $\left(45^{\circ} \mathrm{E}, 75^{\circ} \mathrm{N}\right)$ with temperatures near freezing $\left(-1.9^{\circ} \mathrm{C}\right)$ and 25 salinities near 34.8. The flow continues north-east via the sill, mixing with other water masses including cold fresh Kara Sea water, until it reaches the St Anna Trough where it sinks down the continental slope into the Arctic.

Vertical profiles of potential temperature and salinity, for the representative points 906
OSD

4, 897-931, 2007

Available energy in the Barents Sea

R. C. Levine and

D. J. Webb

Title Page

Abstract Introduction

Conclusions

Tables References

Figures

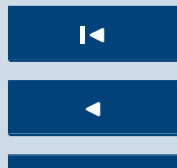

$\Delta$

Back

Close

Full Screen / Esc

Printer-friendly Version

Interactive Discussion

EGU 
marked in Fig. 1, are shown in Fig. 4. In the western and central Barents Sea, illustrated by profiles $A$ and $B$, stratification is weak or non-existant. The temperatures and salinities shown in Figs. 2 and 3 for this region are thus representative of the whole water column. Further east and north, in the St Anna Trough and the offshore Arctic 5 Ocean (profiles $C$ and $D$ ), a fresh surface mixed layer is found with salinities below 33 in the offshore Arctic. Here the mixed layer is around 100m deep and the surface freshening extends down to almost $400 \mathrm{~m}$. In the St Anna Trough the depth and amount of freshening is reduced, but further east in the Kara Sea the near surface salinities are again below 33. The hydrography and flows in the region are discussed further by 10 Aksenov et al. $(2007)^{2}$.

\subsection{Density profiles}

The density profiles for the seven representative stations are shown in Figs. 5 and 6. In Fig. 5, the profiles for the Barents Sea inflow (red) and the Arctic reference region (black) are plotted together with two adiabatic curves (blue). These show how the depth where it is in equilibrium with the offshore water mass.

The near surface water, point $Q$, is denser than that of the Arctic, $P$, so it has the potential to sink down the Arctic continental slope, to $R$, releasing energy. The total amount of gravitational energy released is approximately proportional to the area $P$ $Q-R$. (Eq. 20). Although the offshore is represented here by a single point, $G$, the comparisons and results are similar if one uses an area average of the offshore Arctic.

Deeper in the water column, the water entering the Barents Sea is lighter than that at the same depth in the offshore Arctic. As a result it can release gravitational energy by rising up in the water column. For the bottom water at point $q$ in Fig. 5, the amount

${ }^{2}$ Aksenov, Y., Bacon, S., and Coward, A.: The North Atlantic Inflow into the Nordic Seas and Arctic Ocean:A High-resolution Model Study, Deep-Sea Res. Part I, submitted, 2007.
OSD

4, 897-931, 2007

Available energy in the Barents Sea

R. C. Levine and

D. J. Webb

\section{Title Page}

\section{Full Screen / Esc}

Printer-friendly Version

Interactive Discussion 
of profile $A$ would also tend to settle out near $180 \mathrm{~m}$, so that if it could easily enter the Arctic the whole water column should generate a layer or boundary current at this depth.

The density profiles of Fig. 6 can be interpreted in a similar manner. In the central 5 Barents Sea, location $B$, the whole water column is well mixed so the adiabatic profiles, if plotted, would overlie the actual density profile. The cooling has also increased the density, but although the change is small, the equilibrium depth in the Arctic has increased from $180 \mathrm{~m}$ to nearer $1000 \mathrm{~m}$. Thus it now has the potential of forming one of the deepest layers of the Arctic Ocean.

10 As this water masses passes the sill connecting the region with the St Anna Trough, it mixes with cold fresher water from the Kara Sea and with warm saline Atlantic Water which has followed the longer path north of Spitzbergen. As a result the deeper water in the St Anna Trough may still release energy by sinking into the Arctic, but the equilibrium depth is reduced to $300 \mathrm{~m}$.

\section{$15 \quad 4.3$ Components of available energy}

For analysis of available energy in the Barents Sea we make use of Eqs. (19) and (20). The range of depths involved is only a few hundred metres so the errors from ignoring the density changes due to pressure will be less than $1 \%$.

We need to define a region that is "representative" of the offshore Arctic Ocean. 20 For the results presented in this section we used a region roughly $100 \mathrm{~km}$ by $100 \mathrm{~km}$ surrounding point $G$. Calculations which used a single vertical column at point $G$ as the representative region gave similar results.

In terms of the model variables, the component of $A E$ due to the pressure difference, Eq. (19), is
OSD

4, 897-931, 2007

Available energy in the Barents Sea

R. C. Levine and

D. J. Webb

\section{Title Page}

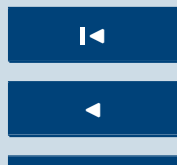

\section{Full Screen / Esc}

Printer-friendly Version

Interactive Discussion

$$
P\left(x, z_{n}\right)=A P(x)+g\left(\left(S S H(x)+d z_{1}\right) \rho\left(x, z_{1}\right)\right.
$$




$$
\left.+\sum_{i=1}^{n-1}\left(d z_{i} \rho\left(x, z_{i}\right)+d z_{i+1} \rho\left(x, z_{i+1}\right)\right)\right) / 2
$$

OSD

4, 897-931, 2007

where $P\left(x, z_{n}\right)$ is the pressure at position $x$ and model level $n, A P$ is the atmospheric pressure, $S S H$ the sea surface height, $g$ gravity, $d z_{i}$ the thickness of model level $i$ and $\rho$ the density. $P_{0}\left(z_{n}\right)$ is the average pressure at level $n$ in the offshore reference region. $5 \quad$ The component due to gravity is

$$
\begin{aligned}
A E_{g}^{\prime}\left(x, z_{n}\right)= & \left(g / \rho^{\prime}\right)\left(\sum_{i=n}^{m} a b s\left(\left(\rho\left(x, z_{i}\right)-\rho_{0}\left(z_{i}\right)\right) d z_{i}\right)\right. \\
& -\left(\left(\rho\left(x, z_{n}\right)-\rho_{0}\left(z_{n}\right)\right) d z_{n}\right. \\
& \left.\left.+\left(\rho\left(x, z_{m}\right)-\rho_{0}\left(z_{m}\right)\right) d z_{m}\right) / 2\right),
\end{aligned}
$$

where $\rho_{0}(z)$ is the density in the offshore region and $z_{m}$ the level at which the initial water mass reaches the same density as the offshore water.

Vertical profiles of these quantities and their sum are shown in Fig. 7, for the water columns discussed previously. Horizontal plots are presented in Figs. 8 to 13, for depths of $25.5 \mathrm{~m}$ and $205 \mathrm{~m}$. These correspond to levels 5 and 21 of the model.

We have taken point $A$ to be representative of the water masses entering the Barents 15 Sea. The point lies on the south side of the deep trough where a current enters the Barents Sea region. It also lies just outside the narrow region of high near surface pressures found along the Norwegian Coast (Fig. 9). Inflow is also found in this region but dynamically it appears to be more complicated. For example the higher pressures, due to high sea level, drop off rapidly towards $30^{\circ} \mathrm{E}$, possibly due to mixing. This is discussed further below.

Near the surface (Fig. 8), the gravitational component of $A E$ is generally low throughout the inflow region. Further south in the Norwegian Coastal Current, values of $A E$ range from $1.1 \mathrm{~J} / \mathrm{kg}$ in the surface fresh water near the coast to $1.7 \mathrm{~J} / \mathrm{kg}$ on the central
Available energy in the Barents Sea

R. C. Levine and

D. J. Webb

\section{Title Page}
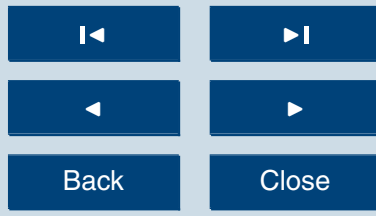

Full Screen / Esc

Printer-friendly Version

Interactive Discussion 
Norwegian Sea side of the current ${ }^{1}$. Most of the inflow to the Barents Sea comes from the coastal side of the current but the value of $1.53 \mathrm{~J} / \mathrm{kg}$ as found at point $A$, although slightly high, is not unreasonable.

\subsection{Vertical profile of $A E$}

5 The profile of $A E$ for point $A$ (Fig. 7) shows that, near the surface, the gravitational component dominates. It drops off rapidly with depth, a result of the rapid reduction in the area integral of Fig. 5, and becomes zero near $180 \mathrm{~m}$, where the density of the water in the main column equals that in the reference region. The gravitational component then increases nearer the bottom.

10 In contrast the pressure component has a minimum at the surface and increases with depth, reaching a maximum at $180 \mathrm{~m}$. Like the reduction in the gravitational term, the increase arises because the water at these depths is denser than that in the reference region. Lower in the water column the pressure difference is steadily reduced.

An important consequence of this behaviour is that the total $A E$ is almost constant 15 throughout the water column. This is because the column is well mixed and because the total $A E$ is independent of the path of integration. If $A E\left(z_{1}\right)$ and $A E\left(z_{2}\right)$ are the values of $A E$ at two depths in the same water column, then from Eq. (13),

$A E\left(z_{1}\right)-A E\left(z_{2}\right)=\int_{z_{1}}^{z_{2}} d z V g\left(\rho(z)-\rho_{1}(z)\right)$.

where $\rho_{1}(z)$ is the density of the water column at depth $z$ and, as before, $\rho(z)$ is the 20 density of the water at $z_{1}$ when moved adiabatically to $z$. If the water is well mixed between two depths, then the value of the integral is zero over the range and the available energy is constant.

\footnotetext{
${ }^{1}$ If fully converted to kinetic energy, an $A E$ of $1 \mathrm{~J} / \mathrm{kg}$ generates a current of approximately $140 \mathrm{~cm} / \mathrm{s}$
}

OSD

4, 897-931, 2007

Available energy in the Barents Sea

R. C. Levine and

D. J. Webb

\section{Title Page}




\subsection{The central Barents Sea}

Reference point $B$ lies near the centre of the dense water region. At the surface the gravitational component of $A E$ increases to near $3.2 \mathrm{~J} / \mathrm{kg}$, over twice its initial value, due to the water getting colder and denser. The pressure component decreases slightly but their sum increases from $1.8 \mathrm{~J} / \mathrm{kg}$ at station $A$ to $3.0 \mathrm{~J} / \mathrm{kg}$ at $B$.

Deeper in the water column, the gravitational component (Fig. 11) drops to around $0.5 \mathrm{~J} / \mathrm{kg}$ and the pressure term (Fig. 12) increases such that the total remains almost constant. What is also interesting here is that the pressure term is similar to that found near $20^{\circ} \mathrm{E}$, along the northern coast of Norway. However there it is due to high sea 10 level whereas at point $B$, where sea level is lower, it is due to high densities in the water column.

\subsection{St. Anna Trough}

Figure 13 shows that the main exit route for the high $A E$ water mass is through the narrow sill region at $58^{\circ} \mathrm{E}, 77.5^{\circ} \mathrm{N}$, into the St. Anna Trough. The total $A E$ has values 15 of around $2.5 \mathrm{~J} / \mathrm{kg}$ at the entrance to the sill. After passing the sill, the value has dropped to around $2.1 \mathrm{~J} / \mathrm{kg}$. The flow then forms a narrow boundary current along the southern and eastern boundaries of the trough. At the same time the available energy continues dropping, to values near $1.8 \mathrm{~J} / \mathrm{kg}$ on the eastern side and to $1.6 \mathrm{~J} / \mathrm{kg}$ at the exit of the trough. The vertical profile of $A E$ remains almost constant near the bottom, so although the current tends to descend in the St Anna Trough, the values of $A E$ shown in Figs. 8 to 13 are similar to the near bottom values.

Comparison of Figs. 11, 12 and 13, shows that the change in $A E$ across the sill is primarily due to the change in pressure. There is a slight increase in kinetic energy, the current increases from $10 \mathrm{~cm} \mathrm{~s}^{-1}$ to $26 \mathrm{~cm} \mathrm{~s}^{-1}$, but in the model the pressure drop 25 is balanced primarily by the bottom friction term in the lowest model layer. Thus $A E$ is being lost overcoming the resistance due to turbulence near the sea bed.

The model uses variable thickness bottom boxes and in this region, where the total

OSD

4, 897-931, 2007

Available energy in the Barents Sea

R. C. Levine and

D. J. Webb

Title Page

Abstract

Introduction

Conclusions

Tables

References

Figures

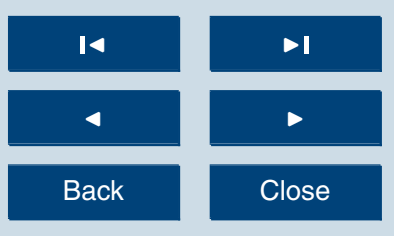

Full Screen / Esc

Printer-friendly Version

Interactive Discussion

EGU 
depth is around $200 \mathrm{~m}$, the bottom model level has a thickness of from 5 to $20 \mathrm{~m}$. Above the bottom, viscous and inertial effects are small, so there is only a slight pressure drop along streamlines. However in the south of the trough, the flow follows topography and so it is strongly affected by bottom friction along most of the path. On the eastern side 5 of the trough the current moves into deeper water and there is less decline in total $A E$.

\subsection{The Arctic Ocean}

At the exit of the St Anna Trough the water mass extends down to $350 \mathrm{~m}$, with values of $A E$ above $1.4 \mathrm{~J} / \mathrm{kg}$. This then forms a band of high $A E$ which can be followed eastwards along the edge of the Siberian Shelf. The model water shows some dense water entering the Arctic from a second trough, the Voronin Trough near $28^{\circ} \mathrm{E}$, but St Anna Trough outflow appears to the dominant water mass involved. Waters with similar $A E$ also enter at this depth directly from the Norwegian Sea, passing north of Spitzbergen, but by the time they reach the St Anna Trough their $A E$ has dropped to below $1.2 \mathrm{~J} / \mathrm{kg}$.

15 As an example, Fig. 14 shows profiles of $A E$ along two sections. Both are roughly at right angles to the continental slope, the first near $155^{\circ} \mathrm{E}$, the second near $180^{\circ} \mathrm{W}$. Water mass with $A E$ greater than $1.3 \mathrm{~J} / \mathrm{kg}$ shows up clearly in both sections adjacent to the continental slope. High values of $A E$ are also found further east as far as the Alaskan continental slope but in this region the separation from the surface layer is less clearly defined.

Profiles of potential temperature and salinity, on the sections of Fig. 14, show a slight dipping of the constant temperature and salinity surfaces near the slope, but they provide no comparable signature to the St Anna Trough waters. It may be possible to use a combined $T / S$ property as a tracer but the present results indicate that, in 25 numerical models at least, $A E$ is a useful independent property that can be used in this way.

OSD

4, 897-931, 2007

Available energy in the Barents Sea

R. C. Levine and D. J. Webb

\section{Title Page}

\section{Full Screen / Esc}

Printer-friendly Version

Interactive Discussion 


\section{Summary and discussion}

This paper has introduced a local version of available energy to quantify the energy available relative to some nearby large body of water. This energy, which is available to accelerate currents and overcome friction, results from the changes in both enthalpy 5 and gravitational potential energy that could occur if the water was to move from its initial position to a position of equilibrium in the reference water column.

We have shown that the available energy can also be expressed as a path integral and that the integral involves two terms. The first depends primarily on the horizontal pressure gradient and the second on the vertical buoyancy force.

\subsection{The Barents Sea}

We have used these results to investigate the energetics of the Barents Sea in a high resolution ocean model. The model shows that the Atlantic inflow in the Norwegian Sea does have significant available energy relatively to the Arctic Ocean, but that this is significantly increased by cooling in the Barents Sea. The cooling also significantly 15 increases the depth at which the Barents Sea water would settle in the Arctic Ocean.

The model also shows that much of the increased available energy is lost to bottom turbulence as the water crosses the Barents Sea and enters the St Anna Trough. However sufficient energy remains for the outflowing St Anna Trough water to be traced far along the continental slope. This means that available energy may be a useful tracer

\subsection{Wider impact}

The results emphasise that even without the Barents Sea, the Alantic inflow has significant available energy relative to the Arctic. As a result it is surprising that there isn't a greater exchange flow through Fram Strait.

Figures 9 and 12 show that there is a significant pressure drop at the strait, geostro-
OSD

4, 897-931, 2007

Available energy in the Barents Sea

R. C. Levine and

D. J. Webb

\section{Title Page}

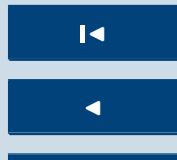

\section{Full Screen / Esc}

Printer-friendly Version

Interactive Discussion 
phy steering much of the Spitzbergen Current into the East Greenland Current. The small throughflow may therefore be due to the limited width of Fram Strait and to the weak stratification, both of which can limit the strength of baroclinic instabilities which could mix the Atlantic water northwards. Weak stratification, together with the rough 5 topography of the region, may also produce topographic blocking of any throughflow.

Given the importance of geostrophy it is noticeable that the only water continuing northwards tends to be in the boundary currents, adjacent to continental slope and the ridge offshore, where frictional effects due to turbulence allow the current to cross pressure contours. The importance of turbulence, in allowing ocean currents to overcome 10 geostrophy and cross pressure contours, is often overlooked. However it is important in western boundary currents and appears to be important in Fram Strait.

The present work also highlights a similar role for turbulence in the Barents Sea where it impedes the flow but also allows the flow to cross pressure contours into the Arctic Ocean. If there were no turbulence, the flow would be geostrophic and presumably there could then be no flow via the Barents Sea into the Arctic.

So turbulence in the Barents Sea may be increasing the flow of Atlantic Water into the Arctic. Further work is needed, for example to check that the Barents Sea transport does not indirectly reduce the Fram Strait transport through some other process. However even if it does, as shown by Levine (2005), the St Anna Trough outflow still has a significant impact on a flow which reaches around the Arctic and Atlantic Oceans as far as Cape Hatteras.

\section{Appendix A}

\section{Total available energy}

25 In analogy with Eq. (1), we define the total available energy $\left(A E_{\text {tot }}\right)$ to be the integral of $A E$ relative to an ocean in which it is in its minimum state. Assume that the water is initially in a reservoir where both the pressure $P_{r}$ and height $z_{r}$ are zero. We split the
OSD

4, 897-931, 2007

Available energy in the Barents Sea

R. C. Levine and

D. J. Webb

\section{Title Page}

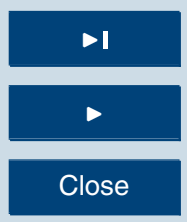

Full Screen / Esc

Printer-friendly Version

Interactive Discussion 
ocean into columns of water and fill each column from the bottom. If $U_{r}$ is the internal energy of the water in the reservoir, then from Eq. (9) the energy required is

$A E=\int d x d y \int_{z_{t}}^{z_{b}} d z \rho\left(H_{1}-U_{r}+g z_{1}\right)$

where $x$ and $y$ are the horizontal coordinates and $z$ the vertical co-ordinate. $H_{1}, U_{r}$ and

$5 \rho$ are functions of all three coordinates and the ocean bottom, $z_{b}$, is a function of $x$ and $y$ only. Substituting for $H_{1}$ and replacing $d x d y d z$ by the volume integral $d V$,

$A E=\int d V \rho\left(U_{1}-U_{r}+P_{1} V_{1}+g z_{b}\right)$.

Substituting for $P_{1}$ from 5 and rearranging,

$A E=\int d V \rho\left(U_{1}-U_{r}+g z\right)$.

10 Thus,

$A E_{\text {tot }}=\int_{V_{1}} d V \rho\left(U_{1}+g z\right)-\int_{V_{0}} d V \rho\left(U_{1}+g z\right)$.

where the second integral is over the minimum $P E$ ocean and the $U_{r}$ terms for the two oceans have cancelled.

As expected the result is equal to the gravitational $A P E$ (Eq. 1) plus the difference in 15 the internal energies of the initial and minimum $A E$ oceans. The latter arises from the different pressure distributions in the two oceans (Eq. 3).

\section{Appendix B}

\section{Terminology}

20 The origin of the concept of enthalpy appears to be in dispute, but Heike KamerlinghOnnes, who received a Nobel prize for his work at low temperatures, is reputed to have
OSD

4, 897-931, 2007

Available energy in the Barents Sea

R. C. Levine and

D. J. Webb

Title Page

Abstract

Introduction

Conclusions

References

Tables

Figures

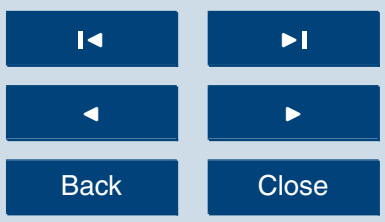

Full Screen / Esc

Printer-friendly Version

Interactive Discussion 
originally defined the enthalpy function $H$,

$H=E+P V$,

OSD

where $E$ is the total energy of the system including the contribution of any external field such as the gravitational potential. If this were still in use then Eq. (9) would describe 5 relative enthalpy. Unfortunately enthalpy as commonly used now (Eq. 7) includes only the internal energy.

Other possibilities besides "available energy" are the terms "relative total enthalpy" and "relative gravitational enthalpy". Note the term "gravitational enthalpy" is also used in describing hydrodynamical equilibrium in the theory of pulsars (Chubarian et al., 10 2007).

Acknowledgements. We wish to thank to A. C. Coward, B. A. De Cuevas and Y. Aksenov for their work in developing and running the OCCAM model and for their help with the present analysis of the archived model data.

\section{References}

15 Chubarian, E., Grigorian, H., Poghosyan, G., and Blaschke, D.: Deconfinement transition in rotating compact stars, http://arxiv.org/abs/astro-ph/9903489v3, 2007. 916

Coward, A. and de Cuevas, B.: The OCCAM 66 level model: model description, physics, initial conditions and external forcing, Tech. rep., Southampton Oceanography Centre, Internal Document No. 99, 83 pp., 2005. 905

20 Landau, L. and Lifshitz, E.: Fluid mechanics, Pergamon Press, 536 pp., 1959. 903

Levine, R.: Changes in shelf waters due to air-sea fluxes and their influence on the Arctic Ocean circulation as simulated in the OCCAM global ocean model, Ph.D. thesis, Graduate School of the Southampton Oceanography Centre, University of Southampton, 255 pp., 2005. 898, 914

25 Lorenz, E.: Available potential energy and the maintenance of the general circulation, Tellus, 7 , 157-167, 1955. 899

Pippard, A.: Elements of Classical Thermodynamics, Cambridge University Press, 165 pp., 1961. 901

Available energy in the Barents Sea

R. C. Levine and

D. J. Webb

Title Page

Abstract

Introduction

Conclusions

Tables

References

Figures

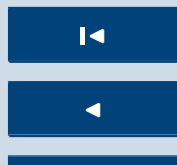

Back

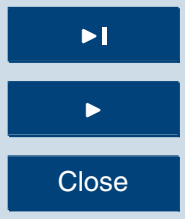

Full Screen / Esc

Printer-friendly Version

Interactive Discussion 
Webb, D., de Cuevas, B., and Coward, A.: The first main run of the OCCAM global ocean model, Tech. Rep. 34, Southampton Oceanography Centre, 44 pp., 1998. 898, 905

Wells, N.: The Atmosphere and Ocean: A Physical Introduction, John Wiley \& Sons, New York, 347 pp., 1997. 899
OSD

4, 897-931, 2007

\section{Available energy in the Barents Sea}

R. C. Levine and

D. J. Webb

Title Page

Abstract

Introduction

Conclusions

References

Tables

Figures

14

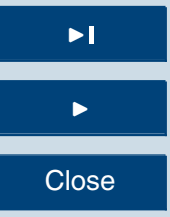

Back

Full Screen / Esc

Printer-friendly Version

Interactive Discussion 

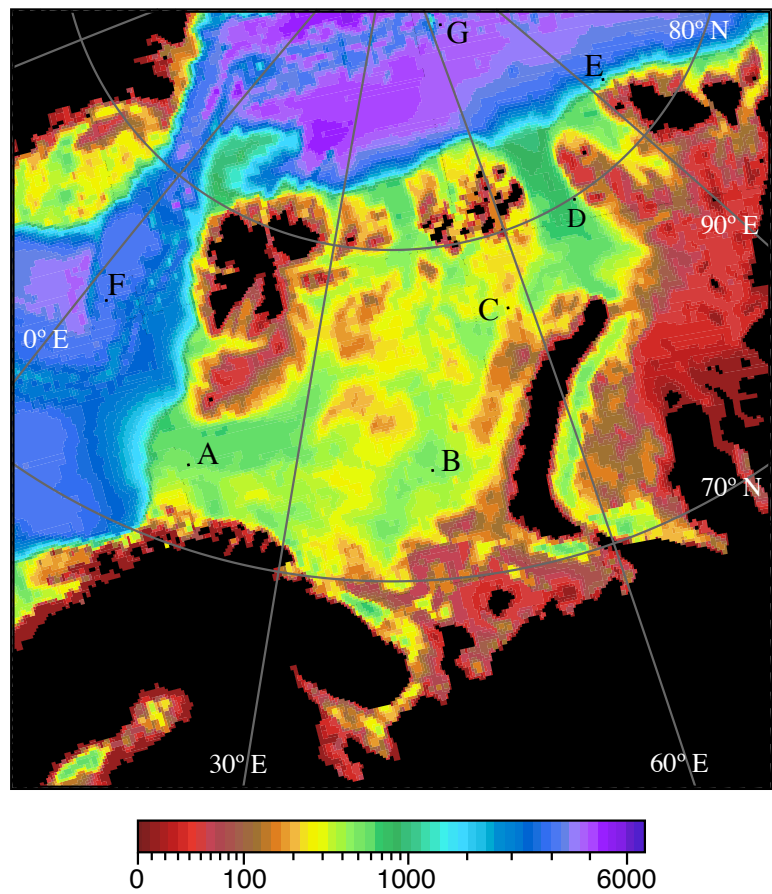

Fig. 1. Bathymetry of the Barents Sea and surrounding regions, showing the depth in metres. The points marked $A$ to $G$ are the positions of the profiles of Figs. 4 to 7 . $A$-Inflow current; $B$ - Central Basin; $C$ - Sill region; $D-$ St Anna Trough; $E$ - Arctic Boundary Current; $F-$ Norwegian Sea; $G$ - Offshore Arctic Ocean reference profile.
OSD

4, 897-931, 2007

Available energy in the Barents Sea

R. C. Levine and

D. J. Webb

\section{Title Page}

Abstract

Introduction

Conclusions

References

Tables

Figures

14

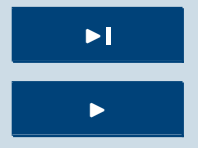

Back

Close

Full Screen / Esc

Printer-friendly Version

Interactive Discussion 
OSD

4, 897-931, 2007
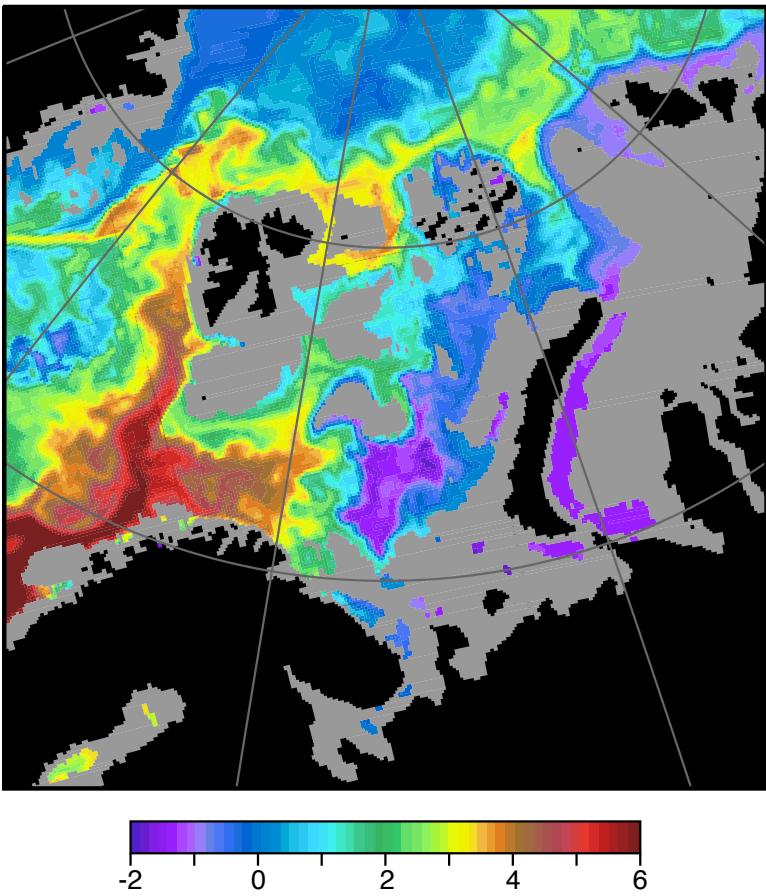

Back

Title Page

Abstract

Introduction

Conclusions

References

Tables

Figures

1

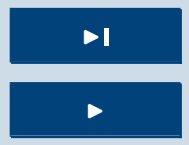

Full Screen / Esc

Fig. 2. Potential temperature $\left({ }^{\circ} \mathrm{C}\right)$ at a depth of $205 \mathrm{~m}$ (model level 21 ).

Printer-friendly Version

Interactive Discussion

EGU 
OSD

4, 897-931, 2007

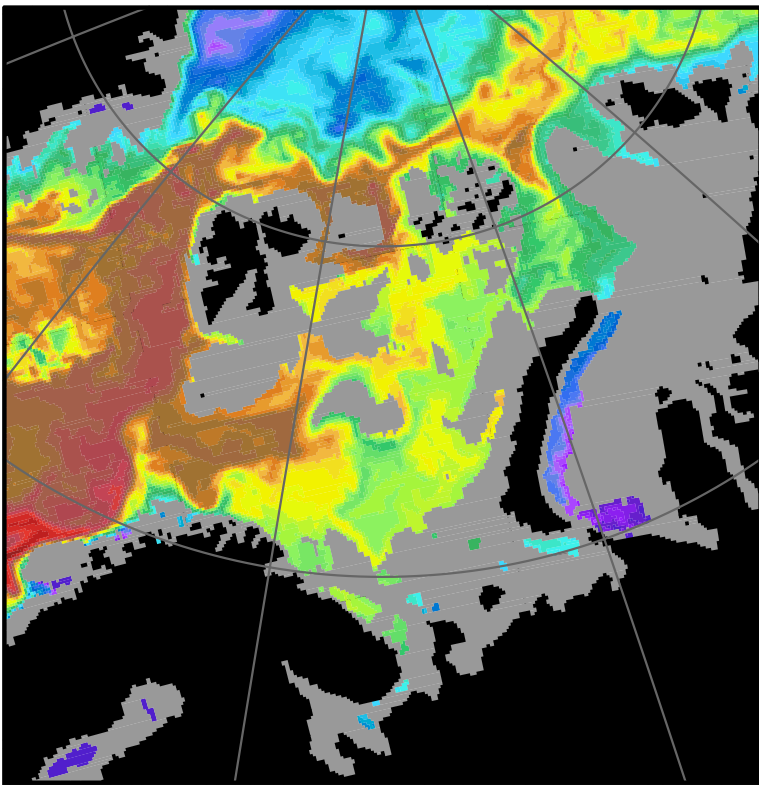

Available energy in the Barents Sea

R. C. Levine and D. J. Webb

Title Page

Abstract

Introduction

Conclusions

References

Tables

Figures

1

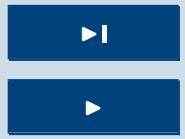

Back

Close

Full Screen / Esc

Printer-friendly Version

Interactive Discussion

EGU 
OSD

4, 897-931, 2007

Available energy in the Barents Sea

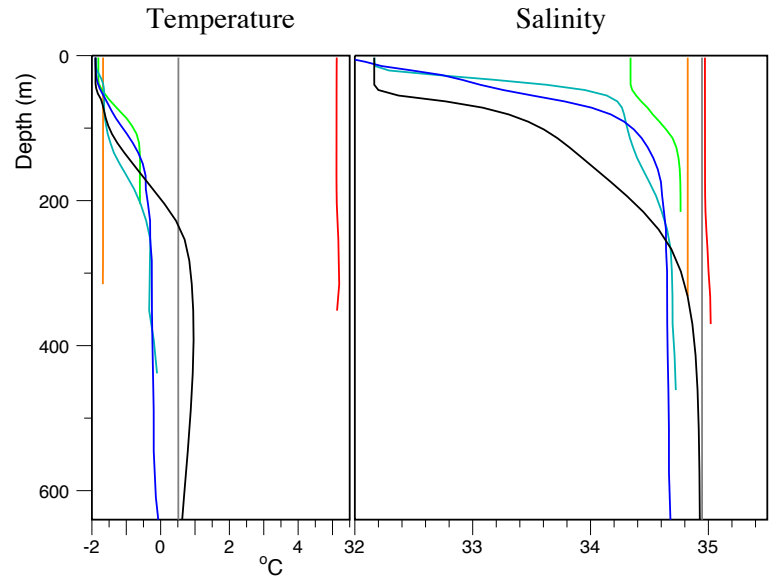

R. C. Levine and D. J. Webb

Title Page

Abstract

Introduction

Conclusions

References

Tables

Figures

14

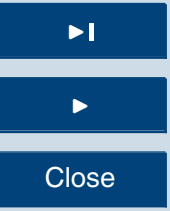
red; $B$ - brown; $C$ - green; $D$ - blue-green; $E$ - blue; $F$ - grey; $G$ - black.

Full Screen / Esc

Printer-friendly Version

Interactive Discussion

EGU 
Density

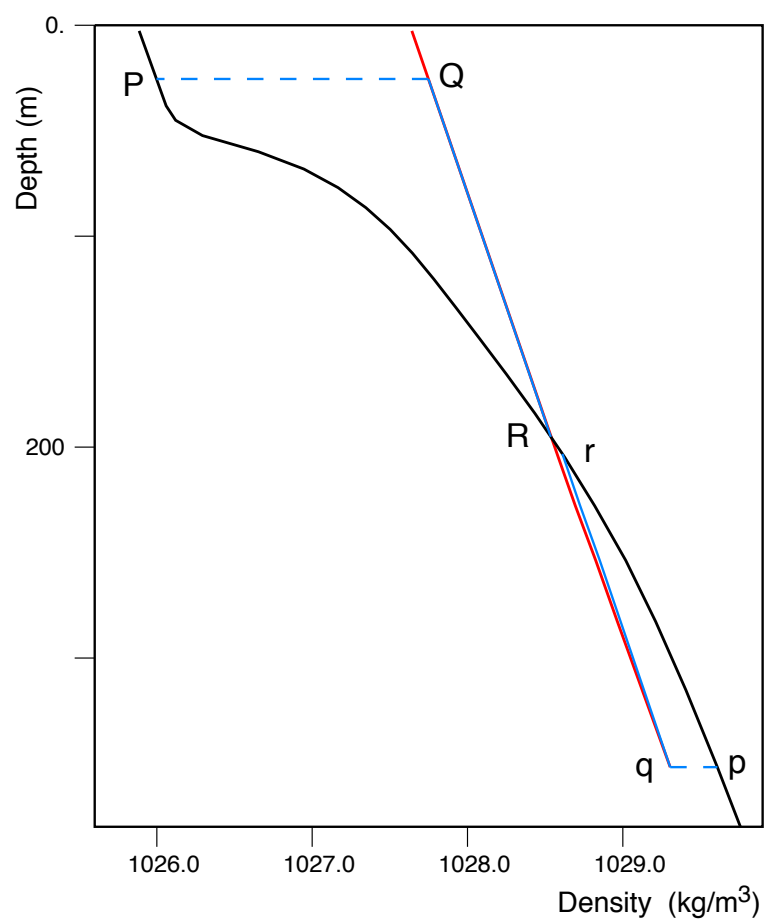

Fig. 5. Density profiles for location $A$ (red), at the Atlantic entrance to the Barents Sea, and for the reference location $G$ (black) in the offshore Arctic. Using Eq. (20), the gravitational part of the available energy at depth $A$, relative to the offshore water column, is proportional to the area of the region $P-Q-R$. The upper blue line $Q-R$ shows the change in the density of the water as it sinks adiabatically to its equilibrium depth offshore. The lower blue line $q-r$ shows the density change as the bottom water on the shelf rises to its equilibrium depth offshore.
OSD

4, 897-931, 2007

Available energy in the Barents Sea

R. C. Levine and D. J. Webb

Title Page

Abstract

Introduction

Conclusions

References

Tables

Figures

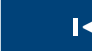

14

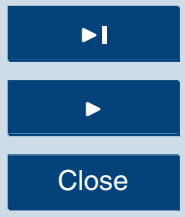

Back

Close

Full Screen / Esc

Printer-friendly Version

Interactive Discussion 


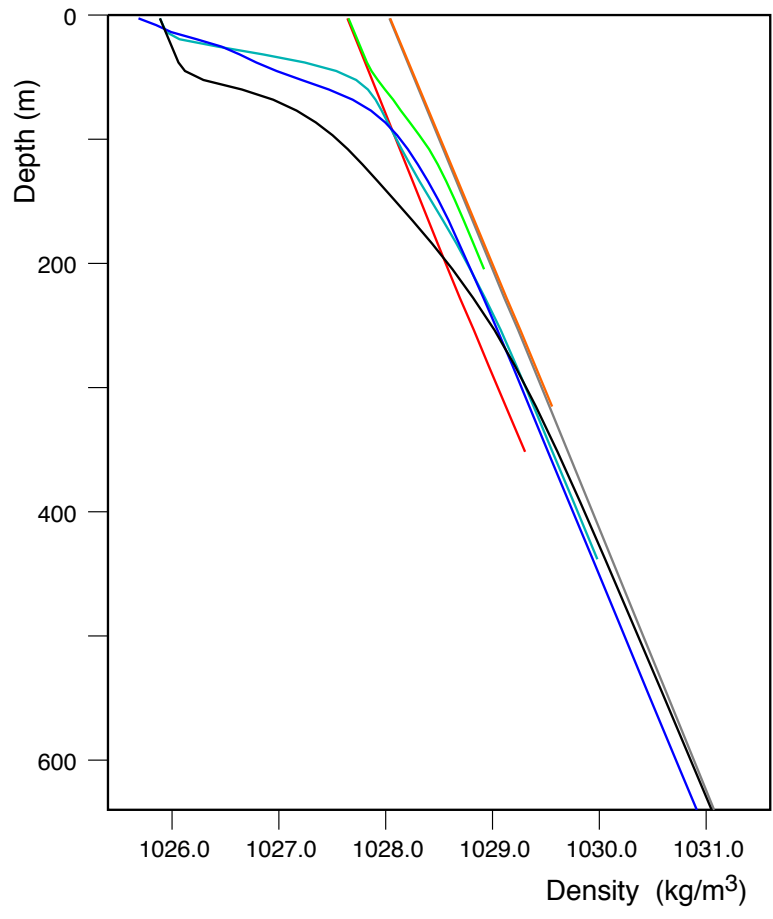

Fig. 6. Density profiles for locations $A$ to $G$ of Fig. 1. Location: $A$-red-Barents Sea inflow; $B$ - brown - Central Basin; $C$ - green - Sill region; $D$ - blue-green - St Anna Trough; $E$ - blue - Arctic Boundary Current; $F$ - grey - Norwegian Sea; $G$ - black - Arctic Ocean reference region.
OSD

4, 897-931, 2007

Available energy in the Barents Sea

R. C. Levine and

D. J. Webb

Title Page

Abstract

Introduction

Conclusions

References

Tables

Figures

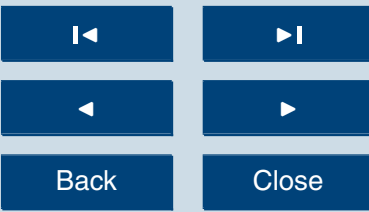

Full Screen / Esc

Printer-friendly Version

Interactive Discussion 
OSD

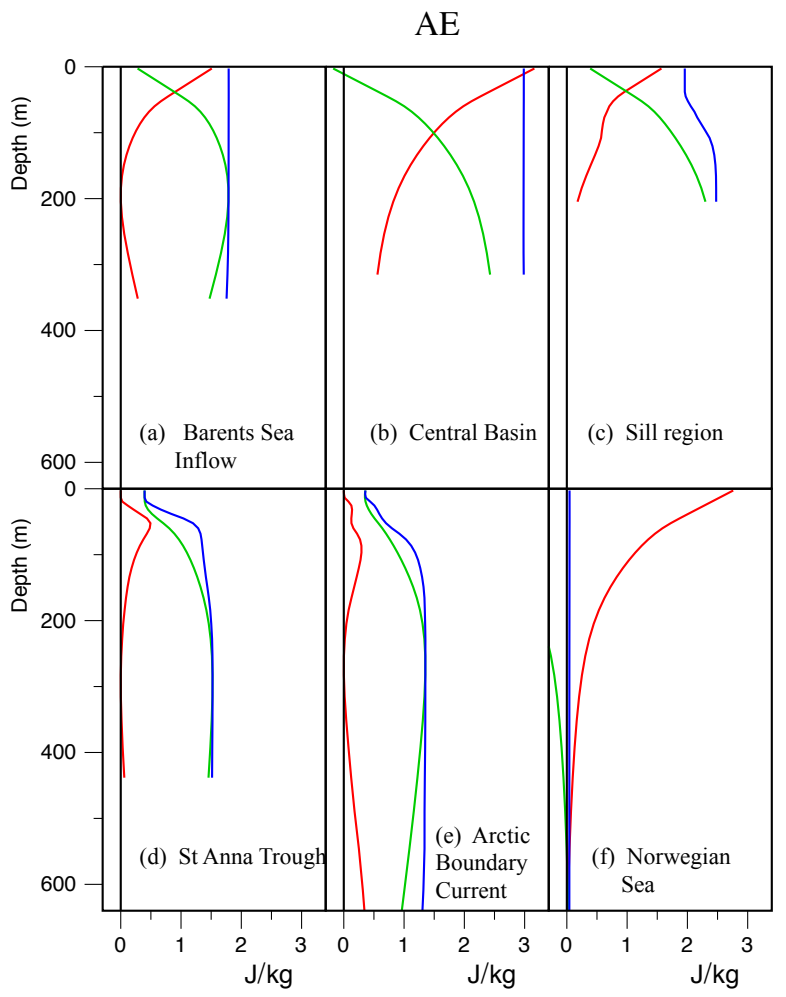

4, 897-931, 2007

\section{Available energy in the Barents Sea}

R. C. Levine and D. J. Webb

\section{Title Page}

Abstract

Conclusions

Tables

1

$\checkmark$

Back

Figures

\section{Full Screen / Esc}

Printer-friendly Version

Interactive Discussion

Fig. 7. Gravitational (red), pressure (green) and
locations $A$ to $F$ of Fig. 1 relative to location $G$. 


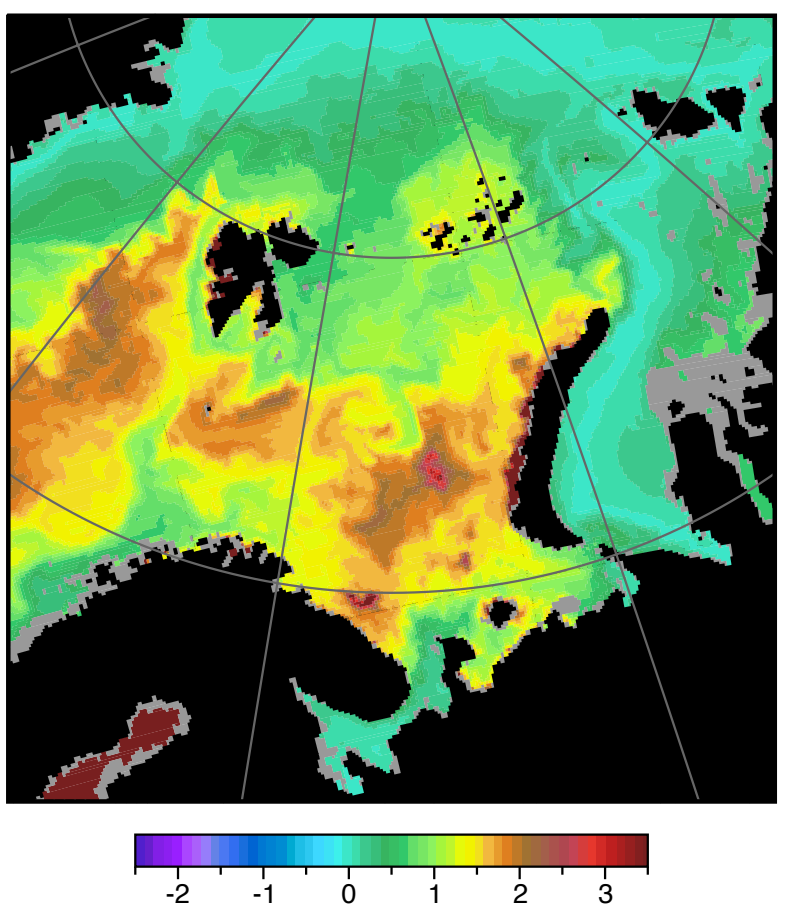

Fig. 8. Gravitational component of available energy $(\mathrm{J} / \mathrm{kg})$ at a depth of $25.5 \mathrm{~m}$ (model level 5).
OSD

4, 897-931, 2007

Available energy in the Barents Sea

R. C. Levine and

D. J. Webb

Title Page

Abstract

Introduction

Conclusions

References

Tables

Figures

$1<$

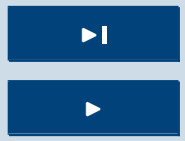

Back

Close

Full Screen / Esc

Printer-friendly Version

Interactive Discussion

EGU 
OSD

4, 897-931, 2007

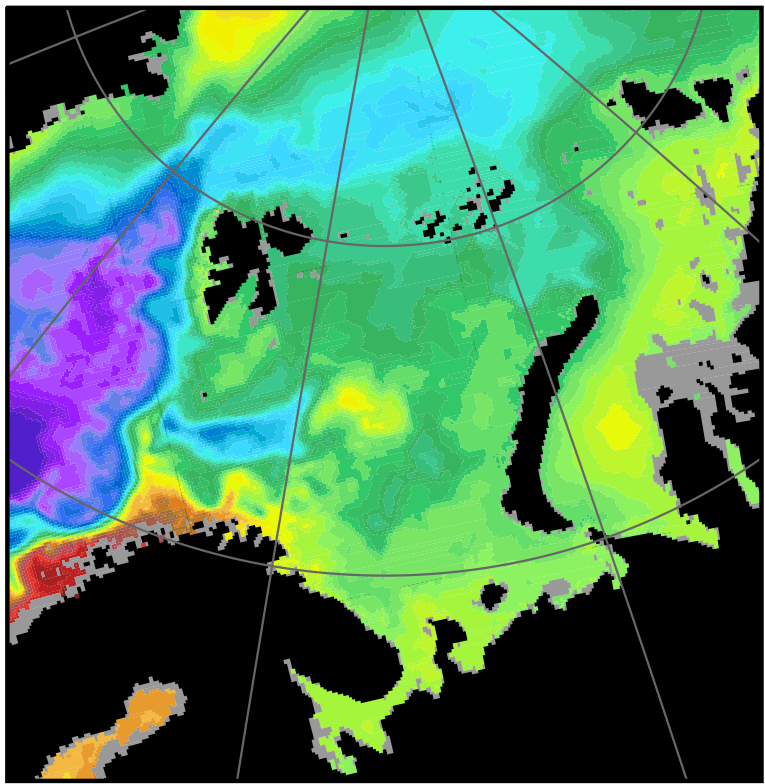

Available energy in the Barents Sea

R. C. Levine and D. J. Webb

Title Page

Abstract

Introduction

Conclusions

References

Tables

Figures

$1<$

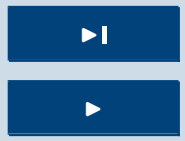

Back

Close

Full Screen / Esc

Printer-friendly Version

Interactive Discussion

EGU 
OSD

4, 897-931, 2007

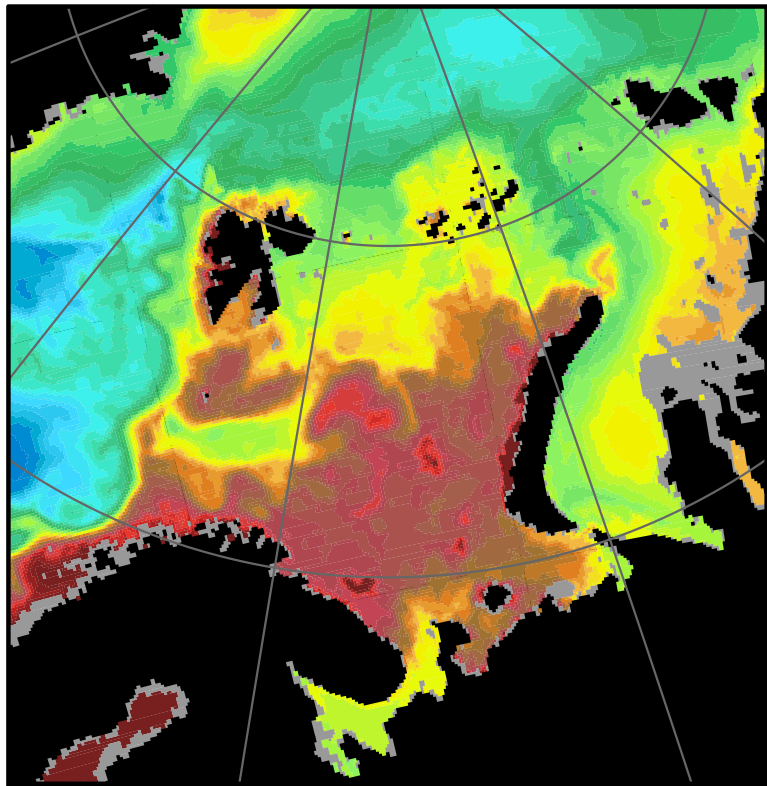

Available energy in the Barents Sea

R. C. Levine and D. J. Webb

Title Page

Abstract

Introduction

Conclusions

References

Tables

Figures

14

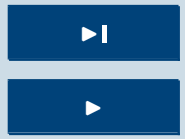

Back

Close

Full Screen / Esc

Printer-friendly Version

Interactive Discussion

EGU 
OSD

4, 897-931, 2007
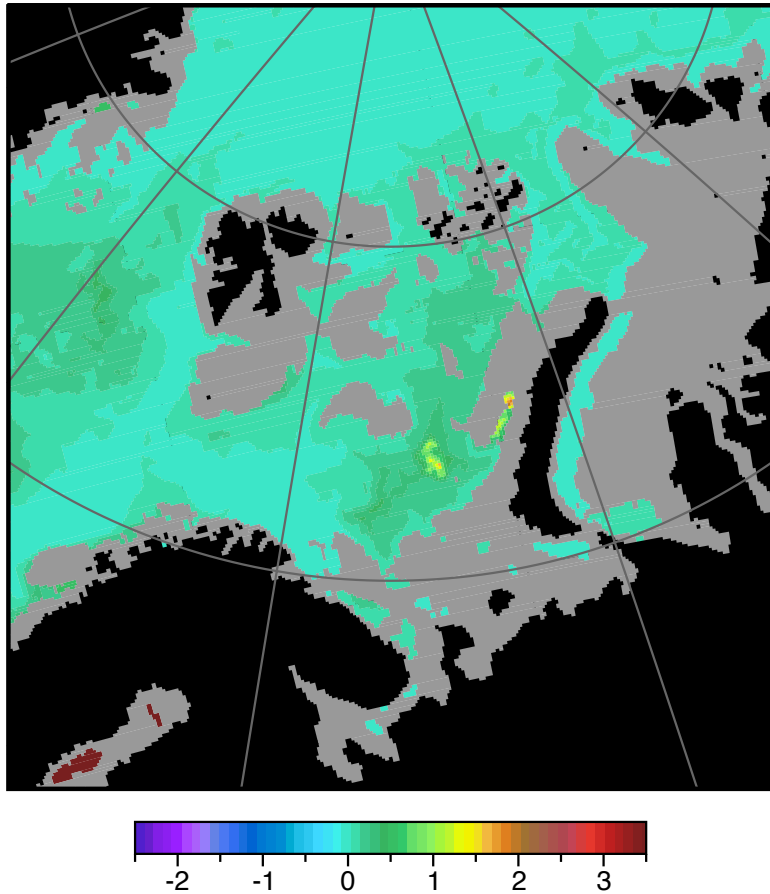

Fig. 11. Gravitational component of available energy $(\mathrm{J} / \mathrm{kg})$ at a depth of $205 \mathrm{~m}$ (model level 21)

\section{Available energy in the Barents Sea \\ R. C. Levine and \\ D. J. Webb}

Title Page

\section{Abstract}

Conclusions

Tables

14

Back

\section{Full Screen / Esc}

Printer-friendly Version

Interactive Discussion 
OSD

4, 897-931, 2007

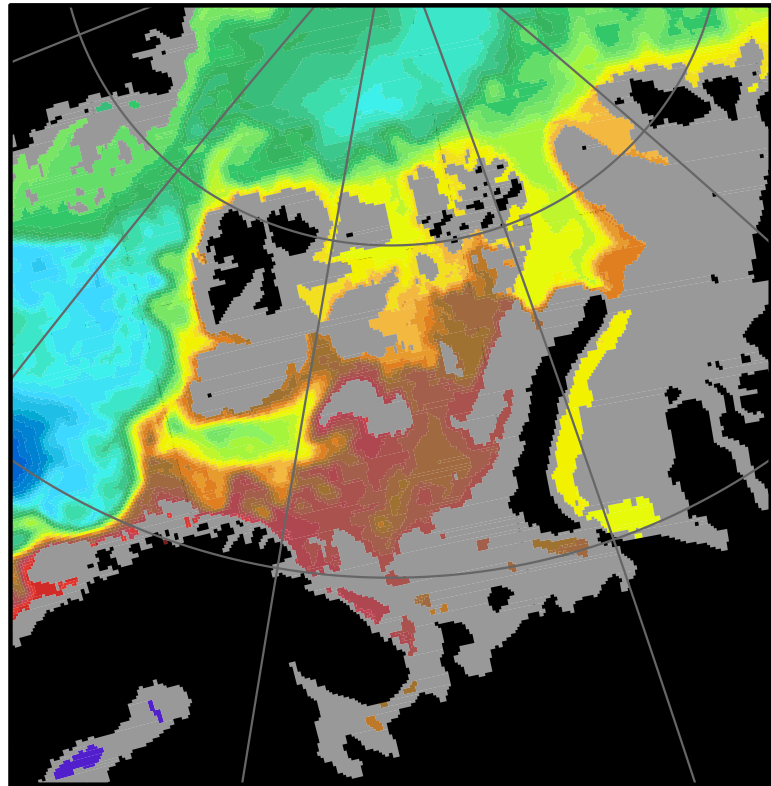

Available energy in the Barents Sea

R. C. Levine and D. J. Webb

Title Page

Abstract

Introduction

Conclusions

References

Tables

Figures

$1<$

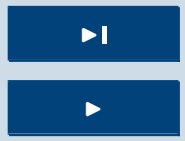

Back

Close

Full Screen / Esc

Printer-friendly Version

Interactive Discussion

EGU 


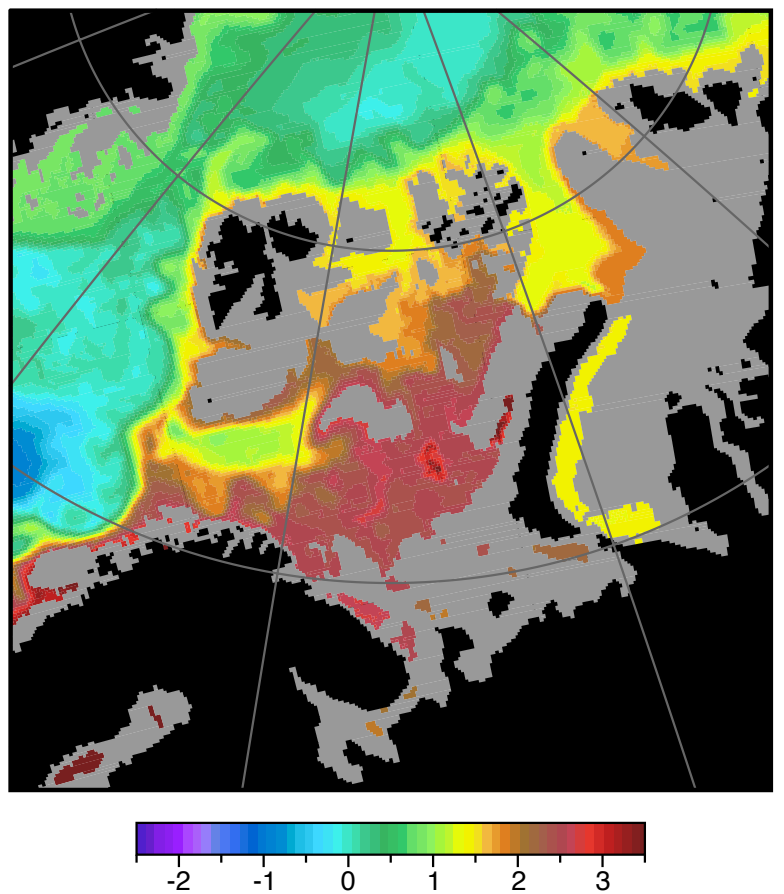

Fig. 13. Total available energy $(\mathrm{J} / \mathrm{kg})$ at a depth of $205 \mathrm{~m}$ (model level 21).
OSD

4, 897-931, 2007

Available energy in the Barents Sea

R. C. Levine and

D. J. Webb

Title Page

Abstract

Introduction

Conclusions

References

Tables

Figures

$1<$

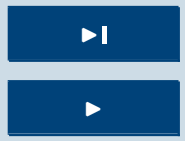

Back

Close

Full Screen / Esc

Printer-friendly Version

Interactive Discussion

EGU 
$\mathrm{AE}$
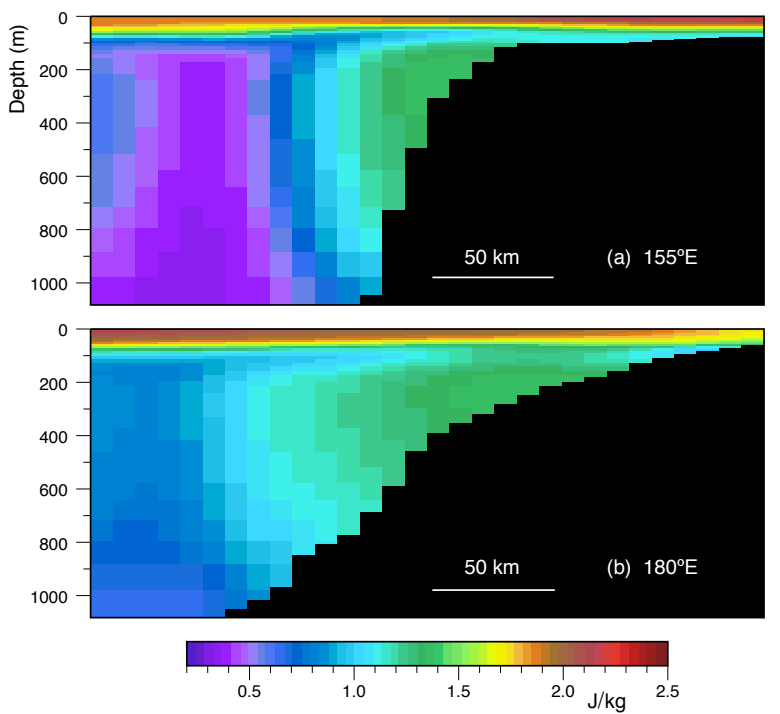

Fig. 14. Available energy ( $\mathrm{J} / \mathrm{kg})$ on sections across the continental slope near (a) $155^{\circ} \mathrm{E}$ and (b) $180^{\circ} \mathrm{E}$. In order to emphasise the core associated with the shelf current, the colour bar differs from that used in Figs. 8 to 13.
Available energy in the Barents Sea

R. C. Levine and D. J. Webb

Title Page

Abstract

Introduction

Conclusions

References

Tables

Figures

14

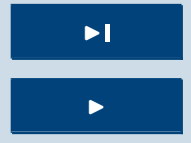

Back

Close

Full Screen / Esc

Printer-friendly Version

Interactive Discussion 